\title{
Mellommenneskelige problemer og psykoterapi
}

\section{Selvrapportering av interpersonlige problemer før behandlingsstart kan gi viktige bidrag til diagnostikk og behandling.}

Mellommenneskelige relasjoner har stor betydning for psykisk helse. Omfattende forskning siden 1950-årene har påvist hvordan mellommenneskelig atferd kan innpasses i to dimensjoner: kjærlighet/hat og dominans/

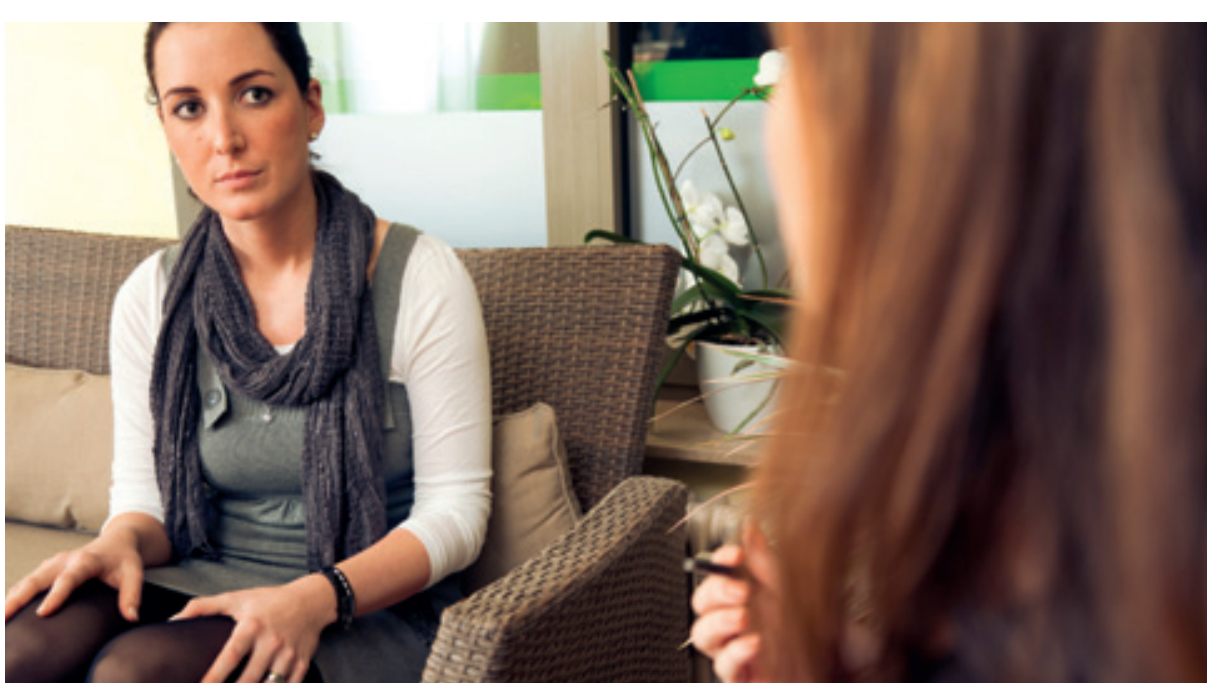

Illustrasjonsfoto Istockphoto

\section{Er det best å vokse opp på landet?}

\section{Sosialt stress virker annerledes på hjernen hos folk i byer. Kan dette forklare den økte risikoen for angstlidelser og schizofreni i urbane strøk?}

Lederbogen og medarbeidere testet hypotesen om at byliv kan påvirke måten hjernen behandler akutt sosialt stress (1). De utsatte friske studenter for regneøvelser, med negative tilbakemeldinger under selve testingen. Hjerneaktiviteten ble målt med funksjonell MR (fMR).

Mange hjernedeler var aktive, men påtakelige forskjeller innen gruppen ble bare funnet i amygdala og deler av gyrus cinguli. Forskjellene var assosiert med både å bo i by og å ha vokst opp i by. De uteble under ustressede, kognitive aktiviteter og kunne ikke forklares av en rekke variabler knyttet til byliv. underkastelse. Det best validerte psykometriske verktøy for måling av mellommenneskelige problemer er Inventory of Interpersonal Problems (IIP-64), som består av 64 spørsmål.
Ved Psykiatrisk poliklinikk i Moss startet vi med registrering av selvrapporteringsdata, bl.a. IIP-64, i 2002. Jeg har sammen med medarbeidere fra Psykologisk institutt, Universitetet i Oslo studert svarene fra 988 pasienter fra poliklinikken og sammenliknet dem med en norsk referansepopulasjon (1).

Vi fant at en stor andel av pasientene rapporterte mellommenneskelige problemer knyttet til lav selvhevdelse (dvs. lave skårer på dominans/underkastelses-dimensjonen). Disse pasientene, med tendens til underkastelse, kan gi utfordringer for terapeuten ved samtaleterapi. Pasienter med interpersonlige problemer knyttet til dominans og fiendtlighet kan gi enda større vansker for terapeuten; slike pasienter kan lett oppfattes som utakknemlige og ubehagelige og risikerer dermed avvisning fra terapeuten.

\section{Espen Bjerke}

espen.bjerke@so-hf.no

Sykehuset $\emptyset$ stfold

Fredrikstad

\section{Litteratur}

1. Bjerke E, Hansen RS, Solbakken OA et al. Interpersonal problems among 988 Norwegian psychiatric outpatients. A study of pre-treatment selfreports. Compr Psychiatry 2011; 52: 273-9. langt fra enkel og kan ikke si hvor det er «best» for mennesker å vokse opp - til det er mulige årsakssammenhenger altfor usikre. Undersøkelsen alene sier heller ikke noe om hvilke mekanismer i hjernen som er ulike hos by- og landboere. Men funnene er interessante som nok en påminnelse om at sosiale forhold «setter spor i hjernen».

\section{Haakon B. Benestad}

h.b.benestad@medisin.uio.no

Universitetet i Oslo til stressopplevelse og stressuttrykk, så funnene passer med antakelser om at byliv medfører mest stress, og at psykiske lidelser er hyppigere i urbane strøk.

I dyreforsøk er det funnet at separasjonstraumer hos nyfødte rotter medfører strukturelle (synaptiske) endringer i gyrus cinguli. Svakere forbindelser mellom gyrus cinguli og amygdala er tidligere assosiert med en genetisk betinget risiko for psykiske lidelser. Tolkingen av MR-funnene er imidlertid
1 Lederbogen F, Kirsch P, Haddad L et al. City living and urban upbringing affect neural social stress processing in humans. Nature 2011; 474: 498-501.
Litteratur 